\title{
IMPROVEMENT OF $\beta$-GLUCOSIDASE PRODUCTION IN Trichoderma harzianum USING MICROBIAL BIOTECHNOLOGY TECHNIQUES.
}

Aboshosha,A. A.*; A. M. El-Bondokly** ; Nosa H. Radwan* and S. A. Dora*

* Dept. of Genetics, Fac. of Agric., Kafrelsheikh Univ.

${ }^{\star *}$ Genetics and Cytology Dept.,National Research Center,Giza

\begin{abstract}
In an attempt to construct superior Trichoderma harzianum isolates for improvement $\beta$-glucosidase productivity, induction of mutants and protoplast fusion techniques were applied. After application of UV irradiation and Ethyl methane sulfonate ( EMS), 461 isolates were obtained, out of them 99 after UV application and 362 isolates after EMS treatments. These isolates were tested for their CMCase and $\beta$-glucosidase productivities in comparison with the original strain. Five isolates (tow after UV application and three after EMS treatments) were selected on the basis of their highly productivity of both enzymes to be treated with colchicine $(0.1 \%$ and $0.2 \%)$ as a second step of mutation induction. After colchicine treatments, 191 isolates were obtained, out of them 40 isolates after treating the wild type strain, 70 isolates after treating the two UV induced-mutants with colchicine and 81 isolates after treating the three EMS induced-mutants with colchicine. These isolates were tested for their CMCase and $\beta$-glucosidase productivities. One isolate (D1/4) proved to be the highest producer for the two enzymes, since it produced $160 \%$ and $186 \%$ CMCase and $\beta$ glucosidase, respectively, more than the original strain. Twenty isolates were selected to be tested for their resistance or sensitivity against four antifungal agents. Out of them four isolates were selected on the basis of their response for antifungal agents and their productivities of two enzymes to be introduced into intraspecific protoplast fusion experiments using two different methods ( PEG and electrofusion). Three crosses were carried out among four selected isolates. The results showed that the numbers of fusants obtained after electrofusion were more than those obtained after PEG method. In addition, highly productivities of CMCase and $\beta$-glucosidase were obtained after electrofusion in three crosses. Highest DNA content and also highest amounts of CMCase and $\beta$ - glucosidase were obtained after EMS-treatments followed by colchicine application
\end{abstract}

\section{INTRODUCTION}

Cellulose constitutes the highest proportion of municipal and wastes, it represents a major source of renewable energy and raw materials. Therefore, the utilization of cellulosic wastes to produce energy is potentially of great importance (Bhat and Bhat, 1997). The enzymatic conversion of cellulose is catalyzed by a multiple enzyme system. Beta-glucosidase ( $\beta$-Dglucoside glucohydrolase, EC 3.2.1.21) is one of the essential enzymes in the enzymatic conversion of cellulose. It is an important component of cellulase system and acts synergistically with endogluconase and cellobiohydrolase for complete degradation of cellulose (Szengyel et al., 2000).

Beta-glucosidase is generally responsible for the regulation of the whole cellulolytic process and is a rate-limiting factor during enzymatic 


\section{Aboshosha,A. A. et al.}

hydrolysis of cellulose, as both endoglucanase and exoglucanase activities are often inhibited by cellobiose. Thus, $\beta$-glucosidase not only produces glucose from cellobiose, but also reduces cellobiose inhibition, allowing endoglucanase and exoglucanase enzymes to function more efficiently (Harhangi et al., 2002).

Trichoderma harzianum is well known as producer of cellulolytic enzymes that extensively used for the degradation of cellulose particularly in textile and paper industries, beside its use in wastewater treatment (Prabavathy et al., 2006).

Strain improvement by mutations is an age - old as a successful method. Therefore, several approaches including chemical mutations, UV irradiations and their combinations were applied to obtain enhanced cellulases producing strains (Kotchoni and Shonukan, 2002). Neverthelese, strains that are genetically improved for high level of cellulases production have been successfully used in a number of applications including animal feed, pharmaceutical and textile industries (Aristidou and Penttilä, 2000).

Fungal protoplasts are an important tool in physiological and genetic research, as well as genetic manipulation can successfully be achieved through fusion of protoplasts in filamentous fungi that lack the capacity for sexual reproduction. (Lalithakumari, 2000).

The aim of the present study is to construct a strain of the fungus $T$. harzianum having the genetic ability to produce the highest CMCase and $\beta$ glucosidase activities.

\section{MATERIALS AND METHODS}

\section{A. MATERIALS:}

\section{A.1. Strain:}

Trichoderma harzianum NRRL 13879 strain was used in the present study, it was provided by United States Department of Agriculture, Agriculture Research Service, National Centre for Agriculture Utilization Research, USA.

\section{A.2. Media:}

A.2.a. Complete medium (CM): (Strauss and Kubicek 1990)

It was used for maintaining and routine culturing .

A.2.b. Minimal medium (MM): (Penttilä et al., 1987)

It was used for isolation of auxotrophic mutants.

A.2.c. Fermentation medium (FM): (Haapala et al., 1995)

It was used for testing CMCase and $\beta$-glucosidase productivities.

A.2.d. Natick medium: (Mandels and Sternberg 1976)

It was used for colchicine treatments.

A.2.e. Protoplasting medium (PM): (Kumari and Panda, 1994)

It was used for the induction of protoplasts in T. harzianum.

A.2.f. Hypertonic, selective and regeneration medium: (Kumari and Panda, 1994) It was used for induction of protoplasts.

\section{A.3. Mutagens:}

A.3.a. Physical mutagen (Ultra - Violet light, UV): 
Philips T UV-30 W, WL 254 nm, lamp type no. 57413 was used for radiation treatments.

A.3.b. Chemical mutagen (Ethyl methane sulfonate, EMS)

A.3.c. Colchicine treatments

Two colchicine treatments with two different concentrations were used with $T$. harzianum .

A.4. Reagents, buffers and solutions :-

A.4.a. Dinitrosalicylic acid assay for reducing sugar (Miller, 1959)

A.4.b. Buffers of mutagens: (Gomori, 1955)

A.4.c. Saline solution: $(0.85 \% \mathrm{NaCl})$ was used in UV treatments.

A.4.d. Fermentation buffer: (Gomori, 1955)

A.4.e. Protoplast preparation and fusion buffers :( Gomori, 1955)

A.4.f. Buffer of DNA isolation: (AI-Samarrai and Schmid 2000).

A.6. Electroporation:

B. METHODS.

Bio -Rad CO., (USA) was used for electroporation process.

B.1. Mutagenic treatments.

B.1.a. UV- light mutagenicity.

B.1.b. EMS mutagenicity.

B.1.c. UV- light followed by colchicine treatments.

B.1.d. EMS followed by colchicine treatments.

B.2. Nuclear staining:-

A piece $(2 \mathrm{~mm} \times 2 \mathrm{~mm})$ was cut from each mycelial mat, stained with Giemsa stain $10 \%$ in phosphate buffer $(\mathrm{pH} \mathrm{6.8)}$ for at least $30 \mathrm{~min}$ and then photographed.

B.3. Auxanographic analysis (Lederberg 1950).

B.4. Fermentation and determination of CMCase and $\beta$-glucosidase activities.

B.4.a. Fermentation procedure:

Conical $250 \mathrm{ml}$ flasks, each containing $50 \mathrm{ml}$ of fermentation media were inoculated with five $\mathrm{ml}$ of the spore suspension from eight days old slants. Flasks were incubated with shaking $(200 \mathrm{rpm})$ at $28^{\circ} \mathrm{C}$ for 10 days.

B.4.b.Determinations of Carboxymethyle cellulase (CMCase) and $\beta$ glucosidase (Vaheri et al., 1979).

B.5. Protoplast fusion:

B.5.a. Isolation of antifungal resistant mutants:

For the isolation antifungal resistant mutants, protoplast medium (PM) and antifungal agents were used separately, concentration of antifungal agents was added as follows:

Benomyle $(0.5$ and $1.0 \mu \mathrm{g} / \mathrm{ml})$; miconzole $(10$ and $25 \mu \mathrm{g} / \mathrm{ml})$ cycloheximide $(75$ and $100 \mu \mathrm{g} / \mathrm{ml})$ and griseofulvin $(250 \mu \mathrm{g} / \mathrm{ml})$. A part of the mycelium of each isolate was inoculated on the surface of the antifungal medium plates, the plates were incubated at $28^{\circ} \mathrm{C}$ for six days. Colonies, which exhibited resistance or sensitivity to a specific antifungal were retested on the same antifungal dose to be sure of their stability concerning resistance or sensitivity . 
Aboshosha,A. A. et al.

B.5.b. Electroporation process (Żukowska et al., 2004).

B.5.c. Isolation of fusants:

Through the present study, PEG or electroporation methods, treated protoplast suspensions were plated onto an antifungal selective medium, which was supplemented with one of the antifungal agents, the plates were incubated at $28{ }^{\circ} \mathrm{C}$ until the colonies were growen on plates surface which considered as complementary fusants. They were transplanted and subcultured several times onto selective medium before further studies.

B.6. Isolation of total DNA from Trichoderma strain and their isolates (Al-Samarrai and Schmid 2000)

\section{RESULTS AND DISCUSSION}

\section{A. Induction of genetic variations:}

Induction of genetic variabilities was carried out using ultraviolet irradiation (UV) or Ethyl methan sulfonate (EMS), each of them was followed by colchicines in another experiment.

\section{A.1. Ultraviolet light mutagenicity (UV):}

Induction of mutations was carried out as a major tool for the induction of a wide range of genetic variations. In the present study, UV irradiation was carried out in different exposure times, i.e., 3 , 6, 9, 12 and 15 min with stirring at a distance of $20 \mathrm{~cm}$ for the induction of mutations in $T$. harzianum NRRL 13879 strain.

The data (not shown) indicated that, 99 colonies were isolated after the application of UV irradiation doses, out of them 24 isolates (24.24\%) showed different characteristics as morphological variants according to both colony shape and color when compared with the parental strain. The highest morphological variants percentage (37.50\%) was appeared as a result of 12 min, UV dose application, and the lowest percentage (11.11\%) was recorded after $15 \mathrm{~min}$. exposure time. Total percentage of the mutants, from application of all UV doses was $24.24 \%$, and all were morphological variants. In addition, results showed that no auxotrophic mutants were obtained after application of UV light.

\section{A.2. Ethyl methane sulfonate treatments (EMS) :}

Fungal spore suspension of $T$. harzianum strain 13879 was treated with five EMS concentrations; 50, 75, 100, 125 and $150 \mu \mathrm{l} / \mathrm{ml}$ for 30 and 60 $\mathrm{min}$. The results showed that, 362 colonies were isolated after applied EMS concentrations and incubation periods, out of them,139 mutants (38.39\%) showed different morphological variants. While, only one mutant proved to be an auxotrophic mutant, it was isolated from the concentration of $100 \mu \mathrm{l} / \mathrm{ml}$ for $60 \mathrm{~min}$. and was identified as (other mutant), since it was requiring more than three requirements tested. Treatment with $75 \mu / \mathrm{ml}$ for 30 min.did not appear any colonies because of the fast growth of the fungus on the medium. Complete lethalty were observed after applied the heighst EMS concentration for $60 \mathrm{~min}$. 


\section{B. Carboxymethyle cellulose and $\beta$-glucosidase activities of $T$. harzianum isolates.}

All selected mutants after every mutagenic treatment were tested for their CMCase and $\beta$. glucosidase activities. Tables (1 and 2) present carboxymethyle cellulase (CMCase) and $\beta$-glucosidase productivities of 461 isolates compared to the original srain, $T$. harzianum NRRL 13879. Out of 461 isolates, 99 were isolated after application of UV doses and 362 isolates were obtained following the different EMS concentrations.

Results in Tables (1 and 2) indicated that, 233 (50.54\%) and 139 $(30.15 \%)$ of the tested isolates produced CMCase and $\beta$-glucosidase activities within the range of the parental strain ( classes $D$ and $H$ in Tables1 and 2, respectively ).

In the case of the 233 isolates, 48 out of them were isolated after UV application and 185 isolates after EMS treatments. But for the 139 isolates, 34 out of them were isolated after UV application and 105 after EMS treatments.

On the other hand, 144 isolates $(31.23 \%)$ proved to be higher CMCase producers than the original strain which produced $2.5 \mathrm{U} / \mathrm{ml}$ CMCase , these isolates were as follow : $97(21.04 \%), 45(9.76 \%)$ and two $(0.43 \%)$ produced at least $20 \%, 60 \%$ and $100 \%$ CMCase, respctively, more than the original strain ( classes $\mathrm{E}, \mathrm{F}$ and $\mathrm{G}$ in Table 1 ), respectively. While, 58 isolates $(12.58 \%)$ produced at least $17 \% \beta$-glucosidase more than the wild type strain which gave $6.0 \mathrm{U} / \mathrm{ml} \beta$-glucosidase (Class I in Table2 ) and 77 isolates $(16.70 \%)$ exhibited $\beta$-glucosidase at least $33.3 \%$ more than the parental strain (Class $\mathrm{J}$ in Table 2 ).

The obtained results showed that, $63(13.66 \%)$ and 170 isolates (36.87\%) exhibited CMCase and $\beta$-glucosidase activities less than the original strain, respectively.While, $21(4.55 \%)$ and (3.68\%) 17 isolates lost completely their abilities to produce any CMCase or $\beta$-glucosidase (classe A in Tables 1 and 2).

Data in Table (3) showed a wide range of CMCase and $\beta$ glucosidase productivities of 99 tested isolates obtained after exposure to different UV doses in comparsion with the original strain, $T$. harzianum NRRL13879, which was considered as $100 \%$ CMCase and $\beta$-glucosidase producer. These results showed that some isolates lost completely their ability to show any CMCase and $\beta$-glucosidase activity , while some other isolates showed activity less than the wild type strain in both enzymes. In addition, some isolates exhibited higher CMCase and $\beta$-glucosidase productivities more than their parental strain, since the best UV-induced mutants for the production of $\beta$-glucosidase were obtained after three and nine min exposure time, while the best activity of CMCase was appeared after $12 \mathrm{~min}$. exposure time. 
Aboshosha,A. A. et al.

T1-2

4242 
Table 3. Evaluate the efficiency of T.harzianum NRRL13879 UV-induced isolates for CMCase and $\beta$-glucosidase productivities.

\begin{tabular}{|l|c|c|c|c|c|}
\hline \multirow{2}{*}{$\begin{array}{l}\text { UV exposure } \\
\text { time (min) }\end{array}$} & $\begin{array}{c}\text { No. of } \\
\text { tested } \\
\text { isolates }\end{array}$ & \multicolumn{3}{|c|}{ Ranges of CMCase and $\boldsymbol{\beta}$-glucosidase (U/ml) } \\
\cline { 3 - 6 } & --- & $\mathbf{2 . 5}$ & $\mathbf{1 0 0 . 0}$ & $\mathbf{6}$ & $\mathbf{1 0 0 . 0}$ \\
\hline Control & 21 & $0.3-3.5$ & $12-140$ & $0.5-9.5$ & $8.3-158.3$ \\
\hline 3 & 24 & $0.0-3.2$ & $0.0-128$ & $0.2-7.5$ & $3.3-125.0$ \\
6 & 21 & $0.0-4.3$ & $0.0-172$ & $0.5-9.5$ & $8.3-158.3$ \\
9 & 24 & $0.0-4.5$ & $0.0-180$ & $0.0-8.0$ & $0.0-133.3$ \\
12 & 9 & $0.2-4.3$ & $8.0-172$ & $0.2-9.2$ & $3.3-153.3$ \\
\hline 15 & &
\end{tabular}

Mutagenic effect of EMS concentrations at 30 and $60 \mathrm{~min}$ on $T$. harzianum NRRL 13879 was appeared in Table (4). Results revealed that the high concentration of EMS (125 $\mu / \mathrm{ml}$ for $30 \mu \mathrm{min})$ gave the best improvement of both enzymes which reached to $100 \%$ and $125 \%$ CMCase and $\beta$-glucosidase more than the untreated parental strain, respectively. Data showed also that some isolates lost some of their CMCase and $\beta$ glucosidase efficiency, after treating the original strain with 75 and $100 \mu \mathrm{l} / \mathrm{ml}$ EMS concentrations for 60 and $30 \mathrm{~min}$, respectively. On the other hand, many of the rest isolates failed completely to show any productivity of both enzymes.

Table 4. Evaluate the efficiency of T.harzianum NRRL 13879 EMS induced mutants for CMCase and $\beta$-glucosidase productivities.

\begin{tabular}{|c|c|c|c|c|c|}
\hline \multirow{2}{*}{$\begin{array}{l}\text { EMS } \\
\text { Conc. }(\mu \mathrm{l} / \mathrm{ml}) \\
\text { time (min) }\end{array}$} & \multirow[b]{2}{*}{$\begin{array}{c}\text { No. tested } \\
\text { isolates }\end{array}$} & \multicolumn{2}{|c|}{ CMCase } & \multicolumn{2}{|c|}{$\beta$-glucosidase } \\
\hline & & $\begin{array}{c}\text { CMCase } \\
(\mathrm{U} / \mathrm{ml})\end{array}$ & \% from W.T. & $\begin{array}{c}\beta \text {-glucosidase } \\
(\mathrm{U} / \mathrm{ml})\end{array}$ & $\%$ from W.T. \\
\hline Control & --- & 2.5 & 100.0 & 6 & 100.0 \\
\hline $50 / 30$ & 29 & $0.0-4.5$ & $0.0-180$ & $0.0-9.5$ & $0.0-158.3$ \\
\hline $50 / 60$ & 26 & $0.0-4.0$ & $0.0-160$ & $0.0-8.0$ & $0.0-133.3$ \\
\hline $75 / 60$ & 37 & $2.0-4.2$ & $80-168$ & $3.5-8.5$ & $58.3-141.7$ \\
\hline $100 / 30$ & 66 & $0.2-4.5$ & $8-184$ & $0.5-13.0$ & $8.3-216.7$ \\
\hline $100 / 60$ & 73 & $0.0-3.5$ & $0.0-140$ & $0.0-8.5$ & $0.0-141.7$ \\
\hline $125 / 30$ & 49 & $0.0-5.0$ & $0.0-200$ & $0.0-13.5$ & $0.0-225$ \\
\hline $125 / 60$ & 50 & $0.0-4.8$ & $0.0-192$ & $0.0-13.0$ & $0.0-216.7$ \\
\hline $150 / 30$ & 32 & $0.0-2.8$ & $0.0-112$ & $0.0-10.5$ & $0.0-175.0$ \\
\hline
\end{tabular}

Five isolates were selected on the basis of their higher CMCase and $\beta$-glucosidase productivities as shown in Table (5). Two isolates out of them were obtained after UV-irradiation, i.e. L (9/8) and P (15/4). They showed (72 $\%$ and $72 \%$ ) CMCase, and (58.3\% and $53.3 \%) \beta$-glucosidase activities more than the original strain, respectively. Other three isolates were obtained as a result of treating T.harzianum NRRL13879 with (E) 50, (R) 100 and (D) 125 $(\mu \mathrm{l} / \mathrm{ml})$ EMS for $30 \mathrm{~min}$ and showed $80 \%, 80 \%$ and $100 \%$ CMCase activity, respectively, as well as $58.3 \%, 116.7 \%$ and $125 \% \beta$-glucosidase activity, more than the original strain. 
Table 5. The highest CMCase and $\beta$-glucosidase producer strains obtained after UV and EMS treatments.

\begin{tabular}{|l|c|c|c|c|}
\hline \multirow{2}{*}{ Enzymes } & \multicolumn{4}{|c|}{ CMCase and $\boldsymbol{\beta}$-glucosidase productivities. } \\
\cline { 2 - 5 } Isolates & $\begin{array}{c}\text { CMCase } \\
(\mathbf{U} / \mathbf{m l})\end{array}$ & \% from W.T. & $\begin{array}{c}\boldsymbol{\beta} \text {-glucosidase } \\
(\mathbf{U} / \mathbf{m l})\end{array}$ & $\%$ from W.T. \\
\hline Control & $\mathbf{2 . 5}$ & $\mathbf{1 0 0 . 0}$ & $\mathbf{6 . 0}$ & $\mathbf{1 0 0 . 0}$ \\
\hline (L) $9 / 8$ & 4.3 & 172.0 & 9.5 & 158.3 \\
(P) $15 / 4$ & 4.3 & 172.0 & 9.2 & 153.3 \\
(E) $50 / 30 / 17$ & 4.5 & 180.0 & 9.5 & 158.3 \\
(R) $100 / 30 / 44 n$ & 4.5 & 180.0 & 13.0 & 216.7 \\
(D) $125 / 30 / 12$ & 5.0 & 200.0 & 13.5 & 225.0 \\
\hline
\end{tabular}

Ultraviolet irradiation and EMS, as a tool for induction of genetic variations was successfully applied by many investigators. The obtained results in this study were in agreement with those obtained by Nadalini et al., (1999), Hao et al., (2006) and Adusl et al., (2007) They isolated different mutants of different Trichoderma species using UV-irradiation.In addition, Kotchoni and Shonukan (2002) isolated forty mutants after treating Trichoderma with EMS, some of them, exhibited a maximum of 10 -fold improvement of cellulase production.

C. Colchicine treatments:

Five isolates mentioned in Table 5 proved to give the highest CMCase and $\beta$-glucosidase activities were treated with two concentrations of colchicines $0.1 \%$ and $0.2 \%(\mathrm{w} / \mathrm{v})$ as a second step of mutations.. Nuclear conditions in mycelial mat were observed by nuclear staining with giemsa solution .

C.1. Carboxymethyle cellulase (CMCase) and $\beta$-glucosidase activities of $T$. harzianum isolates after colchicine treatments:

The grown colonies after colchicine treatments were tested for their CMCase and $\beta$-glucosidase activities.Tables (6 and 7) present the CMCase and $\beta$-glucosidase productivities of 191isolates following colchicine treatments.

Table 6. Distribution and ranges of CMCase productivity $(\mathrm{U} / \mathrm{mI})$ in T.harzianum isolates after colchicine treatments.

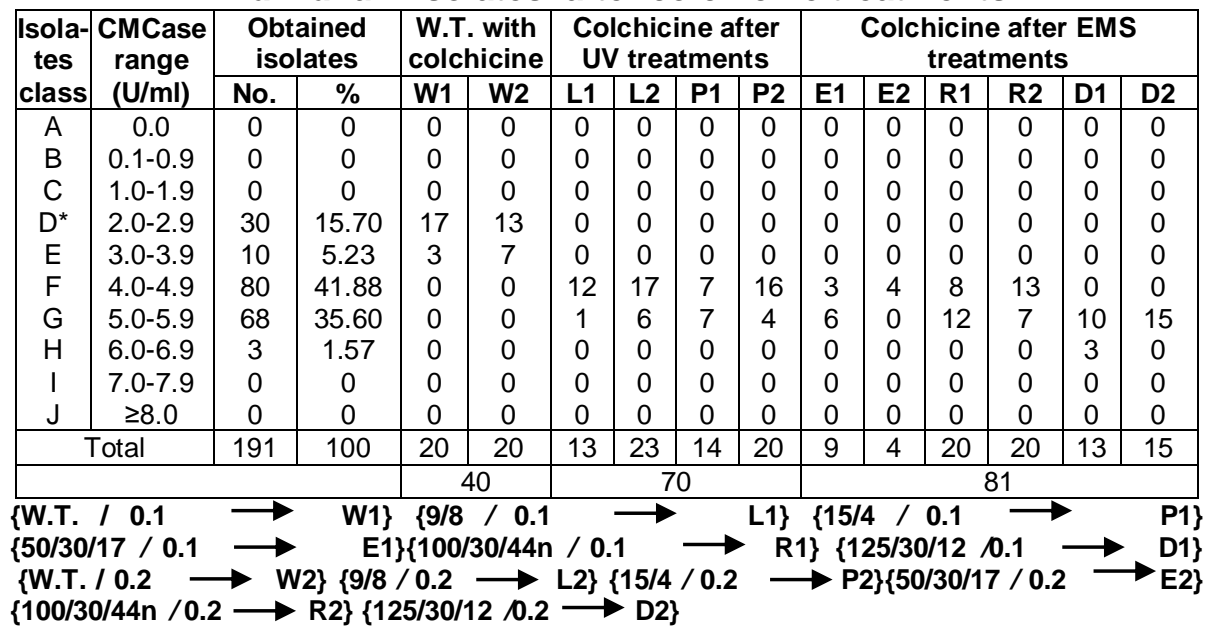


Table 7. Distribution and ranges of $\beta$-glucosidase productivity $(\mathrm{U} / \mathrm{ml})$ in T.harzianum isolates after colchicine treatments.

\begin{tabular}{|c|c|c|c|c|c|c|c|c|c|c|c|c|c|c|c|}
\hline \multirow{2}{*}{$\begin{array}{c}\text { Isola- } \\
\text { tes } \\
\text { class }\end{array}$} & \multirow{2}{*}{\begin{tabular}{|c|}
$\beta-$ \\
glucosi- \\
dase \\
range \\
$(\mathrm{U} / \mathrm{ml})$
\end{tabular}} & \multicolumn{2}{|c|}{$\begin{array}{l}\text { Obtained } \\
\text { isolates }\end{array}$} & \multicolumn{2}{|c|}{$\begin{array}{l}\text { W.T. with } \\
\text { colchicine }\end{array}$} & \multicolumn{4}{|c|}{$\begin{array}{c}\text { Colchicine after UV } \\
\text { treatments }\end{array}$} & \multicolumn{6}{|c|}{ Colchicine after EMS treatments } \\
\hline & & No. & $\%$ & W1 & W2 & L1 & L2 & P1 & P2 & E1 & E2 & R1 & $\mathbf{R 2}$ & D1 & D2 \\
\hline A & 0.0 & 0 & 0 & 0 & 0 & 0 & 0 & 0 & 0 & 0 & 0 & 0 & 0 & 0 & 0 \\
\hline B & $0.1-0.9$ & 0 & 0 & 0 & 0 & 0 & 0 & 0 & 0 & 0 & 0 & 0 & 0 & 0 & 0 \\
\hline C & $1.0-1.9$ & 0 & 0 & 0 & 0 & 0 & 0 & 0 & 0 & 0 & 0 & 0 & 0 & 0 & 0 \\
\hline $\mathrm{D}$ & $2.0-2.9$ & 0 & 0 & 0 & 0 & 0 & 0 & 0 & 0 & 0 & 0 & 0 & 0 & 0 & 0 \\
\hline E & 3.0-3.9 & 0 & 0 & 0 & 0 & 0 & 0 & 0 & 0 & 0 & 0 & 0 & 0 & 0 & 0 \\
\hline $\mathrm{F}$ & $4.0-4.9$ & 0 & 0 & 0 & 0 & 0 & 0 & 0 & 0 & 0 & 0 & 0 & 0 & 0 & 0 \\
\hline $\mathrm{G}$ & 5.0-5.9 & 0 & 0 & 0 & 0 & 0 & 0 & 0 & 0 & 0 & 0 & 0 & 0 & 0 & 0 \\
\hline $\mathrm{H}^{*}$ & 6.0-6.9 & 30 & 15.70 & 17 & 13 & 0 & 0 & 0 & 0 & 0 & 0 & 0 & 0 & 0 & 0 \\
\hline I & 7.0-7.9 & 10 & 5.23 & 3 & 7 & 0 & 0 & 0 & 0 & 0 & 0 & 0 & 0 & 0 & 0 \\
\hline J & $\geq 8.0$ & 151 & 79.05 & 0 & 0 & 13 & 23 & 14 & 20 & 9 & 4 & 20 & 20 & 13 & 15 \\
\hline \multicolumn{2}{|r|}{ Total } & 191 & 100 & 20 & 20 & 13 & 23 & 14 & 20 & 9 & 4 & 20 & 20 & 13 & 15 \\
\hline & & & & \multicolumn{2}{|c|}{40} & \multicolumn{4}{|c|}{70} & \multicolumn{6}{|c|}{81} \\
\hline \multicolumn{3}{|c|}{ 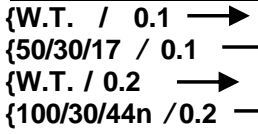 } & & & & & & & $\underset{0.2}{\longrightarrow}$ & \multicolumn{6}{|c|}{ 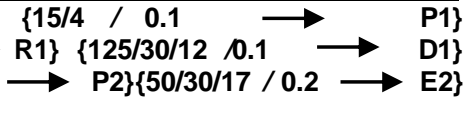 } \\
\hline
\end{tabular}

Results in Tables (6 and 7) showed that after all colchicine treatments, none of the obtained isolates lost its CMCase or $\beta$-glucosidase efficincy or produced less than the original strain, since the lowest productivities for the isolates in classes $\mathrm{D}$ and $\mathrm{H}$ in Tables 6 and 7 were 2.5 and $6.0 \mathrm{U} / \mathrm{ml} \mathrm{CMCase}$ and $\beta$-glucosidase, respectively as the parental strain.

The results indicated that 30 isolates produced CMCase and $\beta$ glucosidase with the same efficiency as the wild type strain, out of them 17 isolates were obtained after treating the original strain with $0.1 \%$ colchicine and 13 isolates after treating the original strain with $0.2 \%$ (classes $\mathrm{D}$ and $\mathrm{H}$ in Tables 6 and 7).

The rest isolates produced CMCase and $\beta$-glucosidase more than the original strain. The best improvement for CMCase activity was resulted from the three mutants isolated after treatment of EMS-mutant $D(125 / 30 / 12)$ with $0.1 \%$ colchicine (D1) as shown in Table (6). These mutants exhibited at least $140 \%$ (class $\mathrm{H}$ ) more than the original strain $T$. harzianum NRRL 13879. On the other hand, 151 isolates $(79.05 \%)$ were obtained after treatment of UV- treated isolates (70) or EMS-treated isolates (81) with the different doses of colchicine. These isolates proved to be higher $\beta$ glucosidase producers, since they produced at least $33.3 \% \quad \beta$-glucosidase more than the original strain.

Moreover, a wide range of CMCase and $\beta$-glucosidase productivities were obtained after colchicine treatments for the original strain and also UV and EMS mutants as shown in Table (8).

Regarding to the best productivities of CMCase, the results showed that, the high concentration of EMS $(125 \mu \mathrm{l} / \mathrm{ml})$ for $30 \mathrm{~min}$ followed by colchicines $0.1 \%$ (D1) gave the highest productivity, since it reached to 160 $\%$ and $30 \%$ more than the original strain and its original mutant, respectively. On the other hand, the same treatment showed $186.7 \%$ and 
27.4 of $\% \beta$-glucosidase activity more than the parental strain and its original mutant, respectively.

For UV-induced mutants, the results showed that the best improvement in $\beta$-glucosidase efficiency reached $110 \%$ and $36.9 \%$ more than the original strain and its original mutant (15/4), respectively, after application with $0.2 \%$ colchicine.

From the above results, it could be noticed that after all treatments the application of colchicine of the concentration of $0.1 \%$ EMS induced-mutants $(125 \mu \mathrm{l} / \mathrm{ml}$ for $30 \mathrm{~min}), \mathrm{D} 1$ exhibited the highest productivity of both enzymes , since it produced $160 \%$ CMCase and $186.7 \% \beta$-glucosidase more than the original strain. In addition, it was considered that, isolates which gave CMCase and $\beta$-glucosidase equal to or less than 5.2 and $14.0 \mathrm{U} / \mathrm{ml}$, respectively, have low enzymes efficiency, while those which gave CMCase and $\beta$-glucosidase equal to or more than 5.8 and $15.5 \mathrm{U} / \mathrm{ml}$, respectively, are highly enzymes producers.

Table 8. Evaluation of CMCase and $\beta$-glucosidase activities for T.harzianum mutants obtained after treatments with UV- or EMS followed by colchicine.

\begin{tabular}{|c|c|c|c|c|c|c|c|}
\hline \multirow[b]{2}{*}{ 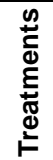 } & \multirow[b]{2}{*}{ 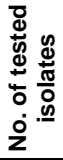 } & \multicolumn{3}{|c|}{ CMCase } & \multicolumn{3}{|c|}{$\beta$-glucosidase } \\
\hline & & $\begin{array}{c}\text { CMCase } \\
\text { (U/ml) }\end{array}$ & $\%$ from W.T. & $\begin{array}{c}\% \text { from UV or } \\
\text { EMS induced } \\
\text { mutant }\end{array}$ & $\underset{\beta-}{\beta-}$ & $\%$ from W.T. & $\begin{array}{c}\text { \% from UV } \\
\text { or EMS } \\
\text { induced } \\
\text { mutant }\end{array}$ \\
\hline \multicolumn{2}{|c|}{ Control } & 2.5 & 100.0 & ----- & 6.0 & 100.0 & ------ \\
\hline W1 & 20 & $2.5-3.0$ & $100.0-120.0$ & $100.0-120.0$ & $6.0-7.5$ & $100.0-125.0$ & $100.0-125.0$ \\
\hline W2 & 20 & $2.5-3.2$ & $100.0-128.0$ & $100.0-128.0$ & $6.0-7.8$ & $100.0-130.0$ & $100.0-130.0$ \\
\hline $\mathrm{L}$ & & 4.3 & 172.0 & 100.0 & 9.5 & 158.3 & 100.0 \\
\hline L1 & 13 & 4.3-5.0 & $172.0-200.0$ & $100.0-116.3$ & $9.5-10.5$ & 158.3-175.0 & $100.0-110.5$ \\
\hline L2 & 23 & 4.3-5.2 & $172.0-208.0$ & $100.0-120.9$ & $9.5-11.5$ & $158.3-191.7$ & $100.0-121.0$ \\
\hline $\mathrm{P}$ & & 4.3 & 172.0 & 100.0 & 9.2 & 153.3 & 100.0 \\
\hline P1 & 14 & 4.3-5.5 & $172.0-220.0$ & $100.0-127.9$ & $9.2-12.5$ & $153.3-208.3$ & $100.0-135.9$ \\
\hline P2 & 20 & 4.3-5.5 & $172.0-220.0$ & $100.0-127.9$ & $9.2-12.6$ & $153.3-210.0$ & $100.0-136.9$ \\
\hline$E$ & & 4.5 & 180.0 & 100.0 & 9.5 & 158.3 & 100.0 \\
\hline E1 & 9 & $4.5-5.2$ & $180.0-208.0$ & $100.0-115.6$ & $9.5-13.5$ & 158.3-225.0 & $100.0-142.1$ \\
\hline E2 & 4 & $4.5-4.8$ & $180.0-192.0$ & $100.0-106.7$ & $9.5-12.5$ & $158.3-208.3$ & $100.0-131.6$ \\
\hline $\mathrm{R}$ & & 4.5 & 180.0 & 100.0 & 13.0 & 216.7 & 100.0 \\
\hline R1 & 20 & $4.5-5.2$ & $180.0-208.0$ & $100.0-115.6$ & $13.0-14.5$ & $216.7-241.7$ & $100.0-111.5$ \\
\hline $\mathrm{R} 2$ & 20 & $4.5-5.2$ & $180.0-208.0$ & $100.0-115.6$ & $13.0-14.5$ & $216.7-241.7$ & $100.0-111.5$ \\
\hline $\mathrm{D}$ & & 5.0 & 200.00 & 100.0 & 13.5 & 225.0 & 100.0 \\
\hline D1 & 13 & $5.0-6.5$ & $200.0-260.0$ & $100.0-130.0$ & $13.5-17.2$ & $225.0-286.7$ & $100.0-127.4$ \\
\hline D2 & 15 & $5.0-5.8$ & $200.0-232.0$ & $100.0-116.0$ & $13.5-16.8$ & $225.0-280.0$ & $100.0-124.4$ \\
\hline
\end{tabular}

Results summarized in Table (9) showed that, 12 out 20 isolates of them were considered as low enzymes producers and eight as highly producers were selected for protoplast fusion experiments.

Two isolates (W1/9 and W2/9) were obtained after treating the original strain with the concentration of $0.1 \%$ and $0.2 \%$ colchicine solution, respectively. Three isolates $(L 1 / 1, L 1 / 9$ and $L 1 / 15)$ were obtained after treating $L(9 / 8)$ mutant with $0.1 \%$ colchicines, while, two isolates (L2/11 and L2/16) were obtained after treating the same UV-induced mutant with $0.2 \%$ colchicine. In addition, two isolates (P1/9 and P2/9) were obtained after 
treating the $P(15 / 4)$ mutant with $0.1 \%$ and $0.2 \%$ colchicine, respectively. Moreover, two isolates ( $\mathrm{E} 1 / 9$ and $\mathrm{E} 2 / 3$ ) were obtained after treating the $\mathrm{E}$ $(50 / 30 / 17)$ mutant with $0.1 \%$ and $0.2 \%$ colchicines, respectively. Only one isolate $(R 2 / 10)$ was obtained after treating the mutant $R(100 / 30 / 44 n)$ with $0.2 \%$ colchicine.

On the other hand, data in Table (9) also showed that eight isolates (D1/1, D1/4, D1/8, D1/14, D2/1, D2/2, D2/4 and D2/11) were considered as highly efficient isolates. The frist four isolates were obtained after treatment the mutant $D(125 / 30 / 12)$ with $0.1 \%$ colchicine, while the rest four isolates were obtained after treated the same EMS mutant with $0.2 \%$ colchicine.

Table 9. CMCase and $\beta$-glucosidase productivities after colchicine treatments.

\begin{tabular}{|c|c|c|c|c|c|c|}
\hline $\begin{array}{c}\text { Parents and } \\
\text { isolates }\end{array}$ & CMCase & $\begin{array}{c}\text { \% from } \\
\text { W.T. }\end{array}$ & $\begin{array}{c}\text { \% from the } \\
\text { original } \\
\text { mutant }\end{array}$ & $\boldsymbol{\beta}$-glucosidase & $\begin{array}{c}\text { \% from } \\
\text { W.T. }\end{array}$ & $\begin{array}{c}\text { \% from the } \\
\text { original } \\
\text { mutant }\end{array}$ \\
\hline W.T. & $\mathbf{2 . 5}$ & $\mathbf{1 0 0 . 0}$ & $\mathbf{1 0 0 . 0}$ & $\mathbf{6 . 0}$ & $\mathbf{1 0 0 . 0}$ & $\mathbf{1 0 0 . 0}$ \\
\hline W1/9 & 3.0 & 120.0 & 120.0 & 7.5 & 125.0 & 125.0 \\
W2/9 & 3.2 & 128.0 & 128.0 & 7.8 & 130.0 & 130.0 \\
L & 4.3 & 172.0 & 100.0 & 9.5 & 158.3 & 100.0 \\
L1/1 & 4.3 & 172.0 & 100.0 & 10.0 & 166.7 & 105.3 \\
L1/9 & 4.3 & 172.0 & 100.0 & 10.5 & 175.0 & 110.5 \\
L1/15 & 5.0 & 200.0 & 116.3 & 10.5 & 175.0 & 110.5 \\
L2/11 & 5.0 & 200.0 & 116.3 & 11.5 & 191.7 & 121.0 \\
L2/16 & 5.2 & 208.0 & 120.9 & 11.5 & 191.7 & 121.0 \\
P & 4.3 & 172.0 & 100.0 & 9.2 & 153.3 & 100.0 \\
P1/9 & 4.3 & 172.0 & 100.0 & 10.5 & 175.0 & 114.1 \\
P2/9 & 5.0 & 200.0 & 116.3 & 11.0 & 183.3 & 119.6 \\
E & 4.5 & 180.0 & 111.1 & 9.5 & 158.3 & 100.0 \\
E1/9 & 5.0 & 200.0 & 116.3 & 10.0 & 165.7 & 105.2 \\
E2/3 & 4.7 & 188.0 & 104.4 & 10.0 & 166.7 & 105.2 \\
R & 4.5 & 180.0 & 100.0 & 13.0 & 216.7 & 100.0 \\
R2/10 & 4.8 & 192.0 & 106.7 & 14.0 & 233.3 & 107.7 \\
D & 5.0 & 200 & 100 & 13.5 & 225.0 & 100.0 \\
D1/1 & 6.2 & 248.0 & 124.0 & 15.5 & 258.3 & 114.8 \\
D1/4 & 6.5 & 260.0 & 130.0 & 17.2 & 286.7 & 127.4 \\
D1/8 & 5.8 & 232.0 & 116.0 & 17.0 & 283.3 & 125.9 \\
D1/14 & 6.0 & 240.0 & 120.0 & 17.2 & 286.7 & 127.4 \\
D2/1 & 5.8 & 232.0 & 116.0 & 16.5 & 275.0 & 122.2 \\
D2/2 & 5.8 & 232.0 & 116.0 & 16.5 & 275.0 & 122.2 \\
D2/4 & 5.8 & 232.0 & 116.0 & 16.8 & 280.0 & 124.4 \\
D2/11 & 5.8 & 232.0 & 116.0 & 16.5 & 275.0 & 122.2 \\
\hline
\end{tabular}

To study the relationship between DNA contents with CMCase and $\beta$ glucosidase productivities, DNA in each of 26 isolates presented herein was isolated and the average DNA content of nucleus was measured. The results (not shown) indicated that, in all cases, colchicine treated isolates proved to contain DNA amounts more than the original mutant isolates with ranges from two to five times as a result of formation of polyploidy (diploids and tetraploids). Also, most isolates which showed highly levels of CMCase and $\beta$-glucosidase productivities proved to contain higher quantities of DNA after colchicine application if compared with their original mutants. 
It can be concluded that EMS-treatments followed by colchicine application were more effective in inducing superior isolates such as D1/4 which showed the highest DNA content, as well as, the highest amounts of CMCase and $\beta$-glucosidase at all.

The obtained results are in agreement with those obtained by Toyama and Toyama (2001), who treated EMS treated isolate of T. reesei ( M14-2) with $0.1 \%$ colchicine. They found that the cellulase production and growth rate of new isolate (M14-2B) were increased. They also concluded that, M14-2B might be constructed using gene sources amplified by additional autopolyploidization from a low growing cellulase hyperproducer, M14-2.

\section{Protoplast fusion}

Protoplast fusion was the main subject to be evaluated in this study as a tool for inducing genetic recombinants especially in those fungi like, T.harzianum, where the sexual cycle is unknown, in order to isolate higher CMCase and $\beta$-glucosidase producing recombinants. However, the use of this technique requires labeling the parental strains before protoplasting and fusion. Some of the highest and lowest CMCase and $\beta$-glucosidase producer isolates and the original strain were used for intraspecific protoplast fusion through this study.

On the basis of the CMCase and $\beta$-glucosidase activities shown in Table (9) and resistance or sensitivity to one or more of four antifungal agents (Benomyle, Miconzole, Cycloheximide and Griseofulvin),only four mutants (L1/15, E2/3, D1/4, and D1/14) were selected to be used in the intraspecific protoplast fusion. Three intraspecific crosses were done using two different methods for each classical (PEG) and electropration methods.

\section{D.1. Intraspecific crosses}

Cross 1

This cross was carried out between two low CMCase and $\beta$ glucosidase producer isolates (L1/15 and E2/3) as shown in Table (10) with the application of two fusion methods. Eleven and 15 recombinants were obtained from this cross on the basis of resistance or sensitivity to both antifungal agents; miconzole and cycloheximide, and named from F1/1 to F1/11 (PEG method) and F4/1 to F4/15 (electoporation method).

The CMCase productivities of the parental isolates (E2/3 and L1/15) were 4.7 and $5.0 \mathrm{U} / \mathrm{ml}$ respectively,while their productivities of $\beta$-glucosidase were 10.0 and10.5 $\mathrm{u} / \mathrm{ml}$ respectively. The highest productivity of both enzymes among 11 fusants obtained from PEG method were recorded by fusants no. F1/6 and F1/10, while they gave $20 \%$ and $14 \%$ of CMCase and $\beta$-glucosidase more than the higher parent ( $L 1 / 15)$, respectively.

While, when CMCase and $\beta$-glucosidase efficiency were determined for the 15 fusants obtained from electroporation method, ten fusants (F4/1, F4/2, $F 4 / 3, F 4 / 4, F 4 / 7, F 4 / 8, F 4 / 9, F 4 / 13, F 4 / 14$ and F4/15) out of them, exhibited higher productivity of both enzymes if compared with the parental isolates. CMCase productivity of these fusants ranged between $20 \%$ produced by fusants (F4/1, F4/4, F4/7, F4/8, and F4/9) to $30 \%$ produced by fusants $(F 4 / 2, F 4 / 3, F 4 / 13, F 4 / 14$ and $F 4 / 15)$ more than the higher parent $(L 1 / 15)$. While, fusants (F4/4, F4/7, F4/8, F4/9, F4/13, F4/14) produced $14.2 \%$ and 19 
$\%$ by fusants (F4/1, F4/2, F4/3 and F4/15) $\beta$-glucosidase more than the higher parent.

Table 10. CMCase and $\beta$-glucosidase productivities for the intraspecific fusants resulted from cross 1

\begin{tabular}{|c|c|c|c|c|c|c|c|c|c|}
\hline \multicolumn{5}{|c|}{ PEG } & \multicolumn{5}{|c|}{ Electroporation } \\
\hline \multirow[b]{2}{*}{$\begin{array}{c}\text { Parents } \\
\text { and } \\
\text { fusants }\end{array}$} & \multicolumn{2}{|c|}{ CMCase } & \multicolumn{2}{|c|}{$\beta$-glucosidase } & \multirow[b]{2}{*}{$\begin{array}{c}\text { Parents } \\
\text { and } \\
\text { fusants }\end{array}$} & \multicolumn{2}{|c|}{ CMCase } & \multicolumn{2}{|c|}{$\beta$-glucosidase } \\
\hline & $\mathrm{U} / \mathrm{ml}$ & $\begin{array}{c}\% \text { from } \\
\text { the } \\
\text { higher } \\
\text { parent }\end{array}$ & $\mathrm{U} / \mathrm{ml}$ & $\begin{array}{c}\% \text { from } \\
\text { the } \\
\text { higher } \\
\text { parent }\end{array}$ & & $\mathrm{U} / \mathrm{ml}$ & $\begin{array}{c}\text { \% from } \\
\text { the } \\
\text { higher } \\
\text { parent }\end{array}$ & $\mathrm{U} / \mathrm{ml}$ & $\begin{array}{c}\text { \% from } \\
\text { the } \\
\text { higher } \\
\text { parent }\end{array}$ \\
\hline W.T. & 2.5 & 50.0 & 6.0 & 75.14 & W.T. & 2.5 & 50.0 & 6.0 & 57.14 \\
\hline $\mathrm{E} 2 / 3$ & 4.7 & 94.0 & 10.0 & 95.23 & $\mathrm{E} 2 / 3$ & 4.7 & 94.00 & 10.0 & 95.23 \\
\hline L1/15 & 5.0 & 100.0 & 10.5 & 100.0 & L1/15 & 5.0 & 100.0 & 10.5 & 100.0 \\
\hline $\mathrm{F} 1 / 1$ & 5.0 & 100.0 & 10.5 & 100.0 & $\mathrm{~F} 4 / 1$ & 6.0 & 120.0 & 12.5 & 119.04 \\
\hline $\mathrm{F} 1 / 2$ & 5.0 & 100.0 & 10.5 & 100.0 & $\mathrm{~F} 4 / 2$ & 6.5 & 130.0 & 12.5 & 119.04 \\
\hline $\mathrm{F} 1 / 3$ & 4.9 & 98.0 & 11.0 & 104.66 & $\mathrm{~F} 4 / 3$ & 6.5 & 130.0 & 12.5 & 119.04 \\
\hline $\mathrm{F} 1 / 4$ & 5.5 & 110.0 & 11.5 & 109.52 & $\mathrm{~F} 4 / 4$ & 6.0 & 120.0 & 12.0 & 114.28 \\
\hline $\mathrm{F} 1 / 5$ & 3.7 & 74.0 & 10.0 & 95.23 & $\mathrm{~F} 4 / 5$ & 4.7 & 94.0 & 10.0 & 95.23 \\
\hline $\mathrm{F} 1 / 6$ & 6.0 & 120.0 & 12.0 & 114.28 & $\mathrm{~F} 4 / 6$ & 4.7 & 94.0 & 10.0 & 95.23 \\
\hline $\mathrm{F} 1 / 7$ & 4.7 & 49.0 & 10.0 & 95.23 & $\mathrm{~F} 4 / 7$ & 6.0 & 120.0 & 12.0 & 114.28 \\
\hline $\mathrm{F} 1 / 8$ & 4.9 & 98.0 & 11.0 & 104.66 & $\mathrm{~F} 4 / 8$ & 6.0 & 120.0 & 12.0 & 114.28 \\
\hline $\mathrm{F} 1 / 9$ & 5.0 & 100.0 & 10.5 & 100.00 & $\mathrm{~F} 4 / 9$ & 6.0 & 120.0 & 12.0 & 114.28 \\
\hline $\mathrm{F} 1 / 10$ & 6.0 & 120.0 & 12.0 & 114.28 & $\mathrm{~F} 4 / 10$ & 4.7 & 94.0 & 10.0 & 95.23 \\
\hline $\mathrm{F} 1 / 11$ & 5.5 & 110.0 & 11.5 & 109.52 & $\mathrm{~F} 4 / 11$ & 5.0 & 100.0 & 10.5 & 100.0 \\
\hline & & & & & $\mathrm{F} 4 / 12$ & 4.3 & 86.0 & 9.5 & 90.47 \\
\hline & & & & & $\mathrm{F} 4 / 13$ & 6.5 & 130.0 & 12.0 & 114.28 \\
\hline & & & & & $\mathrm{F} 4 / 14$ & 6.5 & 130.0 & 12.0 & 114.28 \\
\hline & & & & & $\mathrm{F} 4 / 15$ & 6.5 & 130.0 & 12.5 & 119.04 \\
\hline
\end{tabular}

\section{Cross 2}

The second cross was achieved between highly efficient CMCase and $\beta$-glucosidase producer isolate ( D1/14 ) and the lower efficient one ( E2/3).

Results in Table (11) revealed that only 11 fusants (F2/1 to F2/11) were resulted from the PEG method in comparison with15 fusants (F5/1 to F5/15) were obtained through electroporation method .

Concerning the 11 recombinants obtained from PEG method, it was noticed that five fusants ; (F2/1, F2/5, F2/6, F2/10 and F2/11) showed the higher activity in CMCase and $\beta$-glucosidase production , since they gave 6.8, 6.8, 6.6, 6.8 and $6.6 \mathrm{U} / \mathrm{ml}$ of CMCase, respectively, as well asproduced 18.5, 18.5, $18.0,18.5$ and $18.0 \mathrm{U} / \mathrm{ml}$ of $\beta$-glucosidase, respectively.

In addition, ten fusants (F5/2, F5/3, F5/4, F5/8, F5/9, F5/10, F5/11, $F 5 / 12, F 5 / 14$, and $F 5 / 15$ ) out of 15 obtained from electroporation method showed increase in both CMCase and $\beta$-glucosidase than the higher parental isolate (D1/14). The CMCase values recorded by these fusants ranged between $13.3 \%$ to $20 \%$ more than the higher parent (D1/14). While the amounts of $\beta$-glucosidase ranged between $5.8 \%$ for F5/11 and F5/12 fusants to $7.5 \%$ for the rest eight isolates from the higher parent. 
Aboshosha,A. A. et al.

Table 11. CMCase and $\beta$-glucosidase productivities for the intraspecific fusants resulted from cross 2

\begin{tabular}{|c|c|c|c|c|c|c|c|c|c|}
\hline \multicolumn{5}{|c|}{ PEG } & \multicolumn{5}{|c|}{ Electroporation } \\
\hline \multirow[b]{2}{*}{$\begin{array}{c}\text { Parents } \\
\text { and } \\
\text { fusants }\end{array}$} & \multicolumn{2}{|c|}{ CMCase } & \multicolumn{2}{|c|}{$\beta$-glucosidase } & \multirow[b]{2}{*}{$\begin{array}{c}\text { Parents } \\
\text { and } \\
\text { fusants }\end{array}$} & \multicolumn{2}{|c|}{ CMCase } & \multicolumn{2}{|c|}{$\beta$-glucosidase } \\
\hline & $\mathrm{U} / \mathrm{ml}$ & $\begin{array}{l}\% \text { from } \\
\text { the } \\
\text { higher } \\
\text { parent }\end{array}$ & $\mathrm{U} / \mathrm{ml}$ & $\begin{array}{c}\% \text { from } \\
\text { the } \\
\text { higher } \\
\text { parent }\end{array}$ & & $\mathrm{U} / \mathrm{ml}$ & $\begin{array}{l}\% \text { from } \\
\text { the } \\
\text { higher } \\
\text { parent }\end{array}$ & $\mathrm{U} / \mathrm{ml}$ & $\begin{array}{l}\% \text { from } \\
\text { the } \\
\text { higher } \\
\text { parent }\end{array}$ \\
\hline W.T. & 2.5 & 41.66 & 6.0 & 34.88 & W.T. & 2.5 & 41.66 & 6.0 & 34.88 \\
\hline $\mathrm{E} 2 / 3$ & 4.7 & 78.33 & 10.0 & 58.13 & $\mathrm{E} 2 / 3$ & 4.7 & 78.33 & 10.0 & 58.13 \\
\hline D1/14 & 6.0 & 100.0 & 17.2 & 100.0 & D1/14 & 6.0 & 100.0 & 17.2 & 100.0 \\
\hline $\mathrm{F} 2 / 1$ & 6.8 & 113.33 & 18.5 & 107.55 & $\mathrm{~F} 5 / 1$ & 4.0 & 66.66 & 10.0 & 58.13 \\
\hline $\mathrm{F} 2 / 2$ & 4.7 & 78.33 & 10.0 & 58.13 & $\mathrm{~F} 5 / 2$ & 6.8 & 113.33 & 18.5 & 107.55 \\
\hline $\mathrm{F} 2 / 3$ & 4.7 & 78.33 & 10.0 & 58.13 & $\mathrm{~F} 5 / 3$ & 7.0 & 116.66 & 18.5 & 107.55 \\
\hline $\mathrm{F} 2 / 4$ & 4.0 & 66.66 & 9.0 & 52.32 & $\mathrm{~F} 5 / 4$ & 7.0 & 116.66 & 18.5 & 107.55 \\
\hline $\mathrm{F} 2 / 5$ & 6.8 & 113.33 & 18.5 & 107.55 & $\mathrm{~F} 5 / 5$ & 6.0 & 100.0 & 17.2 & 100.0 \\
\hline $\mathrm{F} 2 / 6$ & 6.6 & 110.0 & 18.0 & 107.55 & $\mathrm{~F} 5 / 6$ & 5.5 & 91.66 & 15.2 & 88.37 \\
\hline $\mathrm{F} 2 / 7$ & 5.2 & 86.66 & 15.2 & 88.37 & $\mathrm{~F} 5 / 7$ & 4.7 & 78.33 & 10.0 & 58.13 \\
\hline $\mathrm{F} 2 / 8$ & 6.0 & 100.0 & 17.2 & 100.00 & $\mathrm{~F} 5 / 8$ & 7.2 & 120.0 & 18.5 & 107.55 \\
\hline $\mathrm{F} 2 / 9$ & 4.7 & 78.33 & 10.0 & 58.13 & $\mathrm{~F} 5 / 9$ & 7.2 & 120.0 & 18.5 & 107.55 \\
\hline $\mathrm{F} 2 / 10$ & 6.8 & 113.33 & 18.5 & 107.33 & $\mathrm{~F} 5 / 10$ & 7.2 & 120.0 & 18.5 & 107.55 \\
\hline $\mathrm{F} 2 / 11$ & 6.6 & 110.00 & 18.0 & 104.65 & $\mathrm{~F} 5 / 11$ & 6.8 & 113.33 & 18.5 & 105.81 \\
\hline & & & & & $\mathrm{F} 5 / 12$ & 6.8 & 113.33 & 18.5 & 105.81 \\
\hline & & & & & $\mathrm{F} 5 / 13$ & 6.0 & 100.0 & 17.2 & 100.0 \\
\hline & & & & & $\mathrm{F} 5 / 14$ & 6.8 & 113.33 & 18.5 & 107.55 \\
\hline & & & & & $\mathrm{F} 5 / 15$ & 7.2 & 120.0 & 18.5 & 107.55 \\
\hline
\end{tabular}

\section{Cross 3}

This cross was done between highly CMCase and $\beta$-glucosidase producer isolates (D1/14 and D1/4).Fourteen fusants were obtained from this cross using PEG method and 15 after application of electroporation method on the basis of antifungal test as shown in Table (12).

All tested fusants showed variable levels of CMCase and $\beta$ glucosidase activities. Out of the 14 tested fusants obtained, six (F3/4, F3/5, $\mathrm{F} 3 / 8, \mathrm{~F} 3 / 9, \mathrm{~F} 3 / 10$ and $\mathrm{F} 3 / 14$ ) proved to have higherproductivity of CMCase and $\beta$-glucosidase if compared with their parents. CMCase productivity of these fusants ranged from $7.5 \mathrm{U} / \mathrm{ml}$ (produced by the fusants $\mathrm{F} 3 / 4, F 3 / 9$, $F 3 / 10$ and $F 3 / 14$ ) to $8.0 \mathrm{U} / \mathrm{ml}$ ( produced by the fusants $F 3 / 5$ and $F 3 / 8$ ). While, $\beta$-glucosidase productivity ofthese fusants ranged from $19.0 \mathrm{U} / \mathrm{ml}$ ( produced by the fusants $F 3 / 4, F 3 / 5, F 3 / 9, F 3 / 10$ and $F 3 / 14$ ) to $19.5 \mathrm{U} / \mathrm{ml}$ (produced by the fusant F3/8).

In addition nine fusants out of the 15 which obtained through electroporation technique proved to have higher productivity of CMCase, out of them four fusants (F6/4, F6/9, F6/10 and F6/14) produced $33 \%$ more than the higher parent (D1/4). While (F6/5, F6/6, F6/11, F6/13 and F6/15) exhibited about $42 \%$ CMCase more than D1/4. Furthermore, ten fusants (F6/2, F6/4, F6/5, F6/6, F6/9, F6/10, F6/11, F6/13, F6/14 and F6/15) proved to have high productivity of $\beta$-glucosidase, their products ranged from $4 \%$ to $16 \%$ more than both parents (D1/4 and D1/14), respectively. 
Table 12. CMCase and $\beta$-glucosidase productivities for the intraspecific fusants resulted from cross 3 .

\begin{tabular}{|c|c|c|c|c|c|c|c|c|c|}
\hline \multicolumn{5}{|c|}{ PEG } & \multicolumn{5}{|c|}{ Electroporation } \\
\hline \multirow[b]{2}{*}{$\begin{array}{c}\text { Parents } \\
\text { and } \\
\text { fusants }\end{array}$} & \multicolumn{2}{|c|}{ CMCase } & \multicolumn{2}{|c|}{$\beta$-glucosidase } & \multirow[b]{2}{*}{$\begin{array}{c}\text { Parents } \\
\text { and } \\
\text { fusants }\end{array}$} & \multicolumn{2}{|c|}{ CMCase } & \multicolumn{2}{|c|}{$\beta$-glucosidase } \\
\hline & $\mathrm{U} / \mathrm{ml}$ & $\begin{array}{l}\% \text { from } \\
\text { the } \\
\text { higher } \\
\text { parent }\end{array}$ & $\mathrm{U} / \mathrm{ml}$ & $\begin{array}{l}\% \text { from } \\
\text { the } \\
\text { higher } \\
\text { parent }\end{array}$ & & $\mathrm{U} / \mathrm{ml}$ & $\begin{array}{l}\% \text { from } \\
\text { the } \\
\text { higher } \\
\text { parent }\end{array}$ & $\mathrm{U} / \mathrm{ml}$ & $\begin{array}{l}\% \text { from } \\
\text { the } \\
\text { higher } \\
\text { parent }\end{array}$ \\
\hline W.T. & 2.5 & 41.66 & 6.0 & 34.88 & W.T. & 2.5 & 38.46 & 6.0 & 34.88 \\
\hline D1/14 & 6.0 & 92.30 & 17.2 & 100.0 & $\mathrm{D} 1 / 14$ & 6.0 & 92.30 & 17.2 & 100.0 \\
\hline $\mathrm{D} 1 / 4$ & 6.5 & 100.0 & 17.2 & 100.0 & $\mathrm{D} 1 / 4$ & 6.5 & 100.0 & 17.2 & 100.0 \\
\hline $\mathrm{F} 3 / 1$ & 6.0 & 92.30 & 17.2 & 100.0 & $\mathrm{~F} 6 / 1$ & 6.5 & 100.0 & 17.2 & 100.0 \\
\hline $\mathrm{F} 3 / 2$ & 6.5 & 100.0 & 17.2 & 100.0 & $\mathrm{~F} 6 / 2$ & 6.5 & 100.0 & 18.0 & 104.65 \\
\hline $\mathrm{F} 3 / 3$ & 5.3 & 81.53 & 15.2 & 88.37 & $\mathrm{~F} 6 / 3$ & 6.3 & 96.92 & 17.2 & 100.0 \\
\hline $\mathrm{F} 3 / 4$ & 7.5 & 115.38 & 19.0 & 110.46 & $\mathrm{~F} 6 / 4$ & 8.0 & 133.33 & 19.5 & 113.37 \\
\hline F3/5 & 8.0 & 123.07 & 19.0 & 110.46 & $\mathrm{~F} 6 / 5$ & 8.5 & 141.66 & 20.0 & 116.27 \\
\hline F3/6 & 6.2 & 95.38 & 17.2 & 100.0 & $\mathrm{~F} 6 / 6$ & 8.5 & 141.66 & 20.0 & 116.27 \\
\hline $\mathrm{F} 3 / 7$ & 6.0 & 92.30 & 17.2 & 100.0 & $\mathrm{~F} 6 / 7$ & 6.0 & 92.30 & 17.2 & 100.0 \\
\hline F3/8 & 8.0 & 123.07 & 19.5 & 113.37 & $\mathrm{~F} 6 / 8$ & 6.0 & 100.0 & 17.2 & 100.0 \\
\hline $\mathrm{F} 3 / 9$ & 7.5 & 115.38 & 19.0 & 110.46 & $\mathrm{~F} 6 / 9$ & 8.0 & 133.33 & 19.5 & 113.34 \\
\hline $\mathrm{F} 3 / 10$ & 7.5 & 115.38 & 19.0 & 110.46 & $\mathrm{~F} 6 / 10$ & 8.0 & 133.33 & 19.5 & 113.34 \\
\hline F3/11 & 6.0 & 92.30 & 17.2 & 100.0 & F6/11 & 8.5 & 141.66 & 20.0 & 116.27 \\
\hline $\mathrm{F} 3 / 12$ & 6.5 & 100.0 & 17.2 & 100.0 & F6/12 & 5.4 & 90.0 & 15.3 & 88.95 \\
\hline $\mathrm{F} 3 / 13$ & 6.5 & 100.0 & 17.2 & 100.0 & F6/13 & 8.5 & 141.66 & 20.0 & 116.27 \\
\hline F3/14 & 7.5 & 115.38 & 19.0 & 110.46 & F6/14 & 8.0 & 133.33 & 19.5 & 113.34 \\
\hline & & & & & F6/15 & 8.5 & 141.66 & 20.0 & 116.27 \\
\hline
\end{tabular}

Comparing both methods of protoplast fusion used in this study (PEG and electroporation), the obtained results clearly showed that the number of fusants obtained after application of electrofusion were more than those obtained after application of PEG method.

On the other hand, higher productivity of CMCase and $\beta$-glucosidase was recorded after electrofusion compared to the PEG method in the three crosses carried out through this study.

Regarding the first cross (Table 10) carried out between two low producer isolates (L1/15 and E2/3), ten fusants obtained after electrofusion method produced from $20 \%$ to $30 \%$ CMCase more than the higher parent $(\mathrm{L} 1 / 15))$. Also, they produced from $14 \%$ to $19 \% \beta$-glucosidase more than the higher parent. On the other hand, four fusants (F1/4, F1/6, F1/10 and, F1/11) obtained after PEG method produced from $10 \%$ to $20 \%$ CMCase, while other five fusants ( F1/3, F1/4, F1/6, F1/8, F1/10 and F1/11) produced $\beta$ glucosidase ranged between $40.66 \%$ and $14.28 \%$ more than the higher parent $(\mathrm{L} 1 / 15)$ as shown in the same Table.

For the second carried out between the lower producer isolate (E2/3) and the higher producer one (D1/14); results in Tabel 11 showed that ten fusants obtained after electrofusion method showed higher productivtity of the two enzymes. The CMCase productivity of these fusants was ranged between $13.3 \%$ and $20 \%$ from the higher parent (D1/14). While, $\beta$ glucosidase productivities was ranged between $5.8 \%$ to $7.5 \%$ from the higher parent. On the other hand, five fusants (F2/1, F2/5, F2/6, F2/10 and F2/11) obtained after PEG method showed from $10 \%$ to $13.3 \%$ CMCase 


\section{Aboshosha,A. A. et al.}

productivity more than the higher parent (D1/14), as well as, produced from $4.6 \%$ to $7.3 \%$ B-glucosidase more than the higher parent (Table 11 ).

In the case of the third cross between the two highly producer isolates (D1/4 and $D / 14$ ), nine fusants obtained from electroporation method ( F6/4, F6/5, $\mathrm{F} 6 / 6, \mathrm{~F} 6 / 9, \mathrm{~F} 6 / 10, \mathrm{~F} 6 / 11, \mathrm{~F} 6 / 13, \mathrm{~F} 6 / 14$, and $\mathrm{F} 6 / 15$ ) recorded $33.3 \%$ to 41.6 $\%$ CMCase more than the higher parent (D1/4) and ten fusants ( $F 6 / 2$, $F 6 / 4, F 6 / 5, F 6 / 6, F 6 / 9, F 6 / 10, F 6 / 11, F 6 / 13, F 6 / 14$, and F6/15) showed from $4.6 \%$ to $16.2 \% \beta$-glucosidase more than both parents. On the other hand, six fusants (F3/4, F3/5, F3/8, F3/9, F3/10 and F3/14) produced $15.3 \%$ to 23 $\%$ CMCase more than the higher parent (D1/4), as well as, showed from $10.4 \%$ to $13.3 \% \beta$-glucosidase productivity more than the two parents. These results were in agreement with those obtained by,Prabavathy et al. (2006) and EL-Bondkly and Talkhan (2007)

In conclusion, there are two main advantages for electroporation method over the traditional PEG method. The first one is simplicity and the second advantage, this method is more reproducible than the classical method (PEG). The improvement of microbial strains was conducted in many research centers and most commonly involve the introduction of additional genes into the cell genome, or an increase in the number of existing genes. The applied protoplast electrofusion method proved to be a good and effective method for obtaining a Trichoderma harzianum fusants with higher productivity of $\beta$-glucosidase enzyme.

\section{REFERENCES}

Al-Samarrai, T.H and J. Schmid (2000). A simple method for extraction of fungal genomic DNA. Letters in Applied Microbiol., 30:53-56.

Adsul, M. G.; K. B. Bastawde; A. J. Verma and D. V. Gokhala (2007). Strain improvement of Penicillium janthinellum NCIM 1171 for increased cellulase production. Bioresource Technology., 98 (7): 1467-1473.

Aristidou, A. and M. Penttilä (2000). Metabolic engineering application to renewable resource utilization., Curr. Opin. Biotechnol. 11:478-483.

Bhat, M. K. and S. Bhat (1997). Cellulose degrading enzymes and their potential industrial application. Biotechnology Advances., 15 (3) : 583620.

EL- Bondkly, A. M and F. N. Talkhan (2007). Intra-strain crossing in Trichoderma harzianum via protoplast fusion to chitinase productivity and biocontrol activity..

Gomori, G. (1955). Preparation of buffers for use in enzyme studies. Method. Enzymol., 1: 138-146.

Haapala, R.; E. Parkkinen; P. Suominen and S. Linko (1995). Production of extracellular enzymes by immobilized Trichoderma reesei in shake flask cultures. Appl. Microbiol. Biotechnol., 43 : 815-821.

Hao, X. C.; X. B. Yu and Z.L. Yan (2006). Optimizition of the medium for the producing of cellulase by the mutant Trichoderma reesei WX-112 using response surface methodology. Food Technol. Biotechnol., 44 (1): 8994. 
Harhangi, H. R.; P. J. M. Steenbakkerrs and V. d. Drift (2002). A highly expressed family $1 \beta$-glucosidase with transglycosylation capacity from the anaerobic fungus Piromyces sp. E2 Biochimica et Biophysica Acta, 1574 (3) : 293-303.

Kotchoni, S. O and O. O. Shonukan (2002). Regualtory mutations affecting the synthesis of cellulase. World Journal of Microbiolgy and biotechnology, 18:487-491.

Kumari, J. A. and T. Panda (1994). Intergeneric hybridization of Trichoderma reesei QM9414 and Saccharomyces cerevisiae NCIM 3288 by protoplast fusion. Enzyme Microb. Technol., $16: 870-882$.

Lalithakumari, D (2000). Fungal protoplasts a biotechnolgical tool. New Delhi, India: Oxford \& IBH publishing company private limited.

Lederberg, J. (1950) Isolation and characterization biochemical mutants of bacteria. In Methods in Medical Research (ed. J. H. Comrie, Jnr. )YearBook Publishers, Ccago.

Mandels, M and D. Sternberg (1976). Recent advances in cellulase technology. J. Ferment Technol 54 : 267-286.

Miller, G. L. (1959). Use of dinitrosalicylic acid reagent for determination of reducing sugar. Anal. Chem., 31: 426-428.

Nadalini, M. F.; A. P. Kleiner and E. C. Cormona (1999). Cellulolytic activity of wild type and mutant Trichoderma pseudokoningii. Journal of Basic Microbiology; 39 : 351-356.

Penttilä, M.; H. Nevalainen ; M. Rättö; E. Salminen and J. Knowles (1987). A versatile transformation system for the cellulolytic filamentous fungus Trichoderma reesei. Gene, 61: 155-164.

Prabavathy, V. R; N. Mathivanam; E. Sagadevani; K. Murugesan and D. Latithakumari (2006b). Intra-strain protoplast fusion enhances carboxymethyl cellulase activity in Trichoderma reesei. Enzyme and Microbial. Technology, 38: 719- 723.

Strauss, J., C.P. Kubicek (1990). $\beta$-Glucosidase and cellulase formation by a Trichoderma reesei mutant defective in constitutive $\beta$-glucosidase formation. J. Gen. Microbiol., 136: 1321-1326.

Szengyel, Z.; G. Zacchi; A. Varga and K. Reczey (2000). Cellulase production of Trichoderma reesei RUT 30 using steam-pretreated spruce. Hydrolytic potential of cellulose on different substrates. Apple Biochem Biotechnol. 84-86 : 679-691.

Toyama, H and N. Toyama (2001). The effect of additional autopolyploidization in a slow growing cellulase hyperproducer of Trichoderma. Appl. Biochem.,Biotechnol., 91-93: 787-790.

Vaheri, M. P; M. E. O. Vaheri and V. S. Kauppine. (1979). Formation and release of cellulolytic enzymes during growth of Trichoderma reesei on cellobiose and glycerol. Eur. J. Appl. Microbiol. Biotechnol., 8 : 73-80.

Żukowska,S;D. Juszakiewicz; A.Misiewicz; A.Krakawiak and B. Jedrychawska (2004). Intensification of lipase biosynthesis as a result of electrofusion of Rhizopus cohnii protoplasts. J.AppL.Genet., 45 (1): 37-48. 
Aboshosha,A. A. et al.

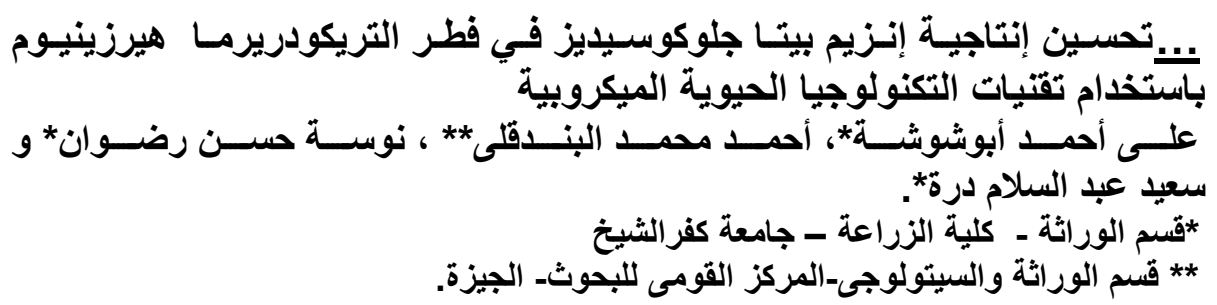

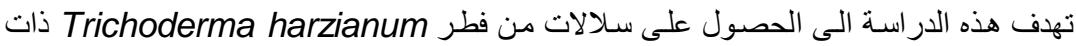

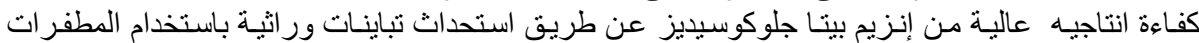

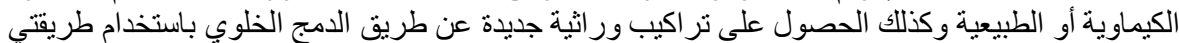

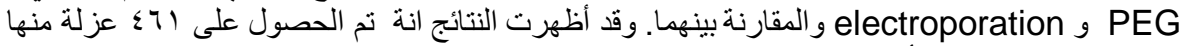

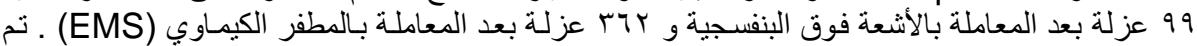

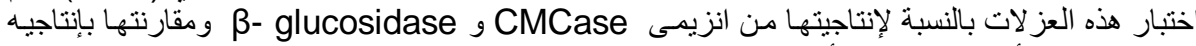

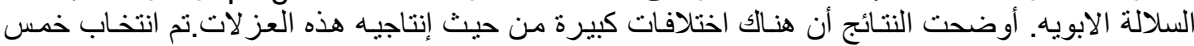

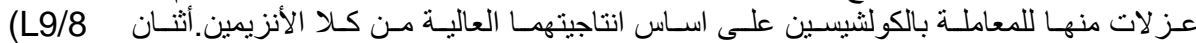

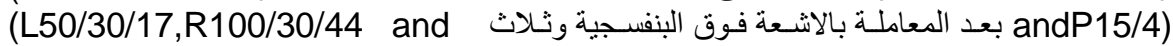

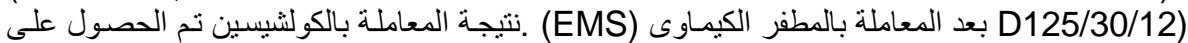

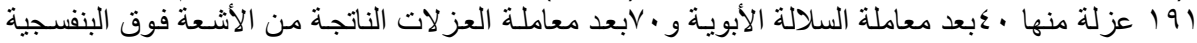

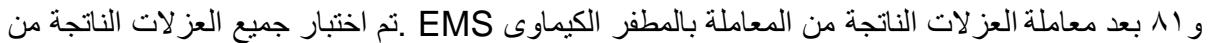

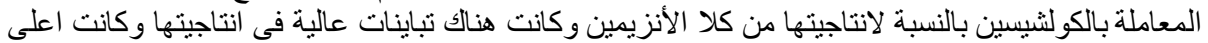

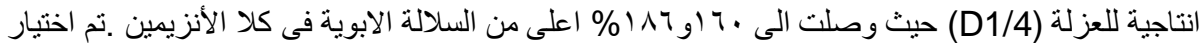

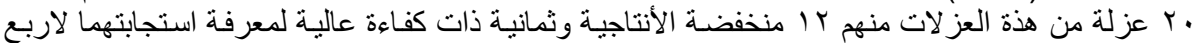

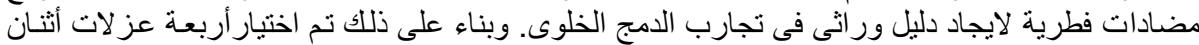

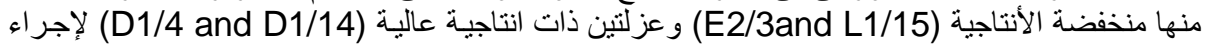

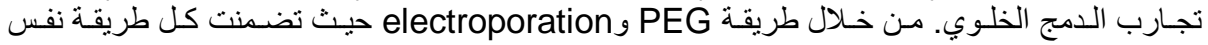

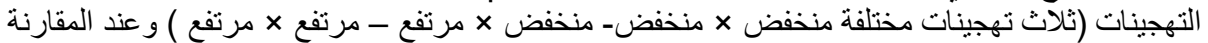

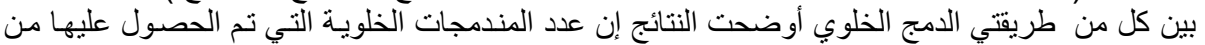

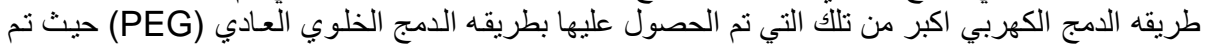

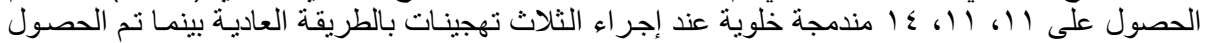

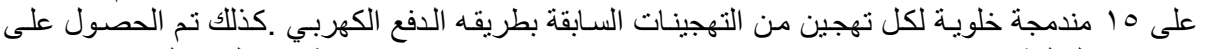

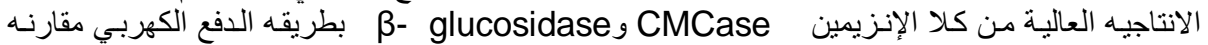

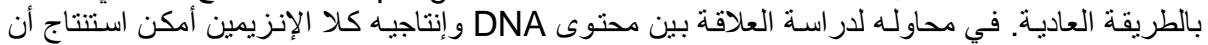

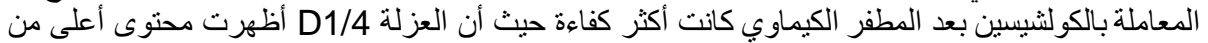

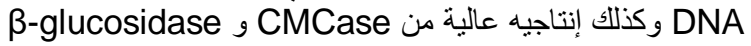


J. Agric. Sci. Mansoura Univ., 34 (5): 4237 - 4254, 2009

Table 1. Distribution and ranges of CMCase activity $(\mathrm{U} / \mathrm{ml})$ in T.harzianum isolates after mutagenic treatments .

\begin{tabular}{|c|c|c|c|c|c|c|c|c|c|c|c|c|c|c|c|c|}
\hline \multirow[t]{2}{*}{$\begin{array}{l}\text { Isolates } \\
\text { class }\end{array}$} & \multirow[t]{2}{*}{$\begin{array}{c}\text { CMCase } \\
\text { range }(\mathrm{U} / \mathrm{ml})\end{array}$} & \multicolumn{2}{|c|}{$\begin{array}{c}\text { Obtained } \\
\text { isolates }\end{array}$} & \multicolumn{5}{|c|}{$\begin{array}{c}\text { UV exposure time } \\
\text { (min) }\end{array}$} & \multicolumn{8}{|c|}{ EMS $(\mu \mathrm{l} / \mathrm{ml}) /$ time $(\min )$} \\
\hline & & No. & $\%$ & 3 & 6 & 9 & 12 & 15 & $50 / 30$ & $50 / 60$ & $75 / 60$ & $100 / 30$ & $100 / 60$ & $125 / 30$ & $125 / 60$ & $150 / 30$ \\
\hline A & 0.0 & 21 & $4 . .55$ & 0 & 1 & 1 & 2 & 0 & 4 & 2 & 0 & 0 & 6 & 1 & 2 & 2 \\
\hline B & $0.1-0.9$ & 30 & 6.50 & 5 & 1 & 2 & 5 & 1 & 2 & 1 & 0 & 4 & 3 & 2 & 0 & 4 \\
\hline C & $1.0-1.9$ & 33 & 7.15 & 0 & 1 & 2 & 0 & 0 & 0 & 1 & 0 & 15 & 8 & 2 & 2 & 2 \\
\hline$D^{*}$ & $2.0-2.9$ & 233 & 50.54 & 7 & 13 & 14 & 12 & 2 & 15 & 15 & 17 & 34 & 52 & 16 & 12 & 24 \\
\hline E & $3.0-3.9$ & 97 & 21.04 & 9 & 8 & 1 & 4 & 2 & 6 & 6 & 13 & 10 & 4 & 12 & 22 & 0 \\
\hline $\mathbf{F}$ & $4.0-4.9$ & 45 & 9.76 & 0 & 0 & 1 & 1 & 4 & 2 & 1 & 7 & 3 & 0 & 14 & 12 & 0 \\
\hline G & $5.0-5.9$ & 2 & 0.43 & 0 & 0 & 0 & 0 & 0 & 0 & 0 & 0 & 0 & 0 & 2 & 0 & 0 \\
\hline H & $6.0-6.9$ & 0 & 0 & 0 & 0 & 0 & 0 & 0 & 0 & 0 & 0 & 0 & 0 & 0 & 0 & 0 \\
\hline I & 7.0-7.9 & 0 & 0 & 0 & 0 & 0 & 0 & 0 & 0 & 0 & 0 & 0 & 0 & 0 & 0 & 0 \\
\hline$J$ & $\geq 8.0$ & 0 & 0 & 0 & 0 & 0 & 0 & 0 & 0 & 0 & 0 & 0 & 0 & 0 & 0 & 0 \\
\hline \multicolumn{2}{|l|}{ Total } & 461 & 100 & 21 & 24 & 21 & 24 & 9 & 29 & 26 & 37 & 66 & 73 & 49 & 50 & 32 \\
\hline
\end{tabular}

$D^{*}$ including the original strain which produced $2.5 \mathrm{U} / \mathrm{ml}$

Table 2. Distribution and ranges of $\beta$-glucosidase productivity $(\mathrm{U} / \mathrm{ml})$ in T.harzianum isolates after mutagenic treatments.

\begin{tabular}{|c|c|c|c|c|c|c|c|c|c|c|c|c|c|c|c|c|}
\hline \multirow[t]{2}{*}{ Isolates class } & \multirow{2}{*}{$\begin{array}{c}\beta \text {-glucosidase } \\
\text { range } \\
(\mathrm{U} / \mathrm{ml})\end{array}$} & \multicolumn{2}{|c|}{$\begin{array}{l}\text { Obtained } \\
\text { isolates }\end{array}$} & \multicolumn{5}{|c|}{$\begin{array}{c}\text { UV exposure time } \\
\text { (min) }\end{array}$} & \multicolumn{8}{|c|}{ EMS $(\mu \mathrm{l} / \mathrm{ml}) /$ time $(\mathrm{min})$} \\
\hline & & No. & $\%$ & 3 & 6 & 9 & 12 & 15 & $50 / 30$ & $50 / 60$ & $75 / 60$ & $100 / 30$ & $100 / 60$ & $125 / 30$ & $125 / 60$ & $150 / 30$ \\
\hline$A$ & 0.0 & 17 & 3.68 & 0 & 0 & 0 & 1 & 0 & 2 & 1 & 0 & \begin{tabular}{|l|}
0 \\
\end{tabular} & 6 & 1 & 2 & 4 \\
\hline B & $0.1-0.9$ & 26 & 5.63 & 2 & 1 & 3 & 4 & 1 & 6 & 4 & 0 & 1 & 2 & 0 & 0 & 2 \\
\hline C & $1.0-1.9$ & 15 & 3.25 & 3 & 0 & 1 & 0 & 0 & 3 & 0 & 0 & 0 & 0 & 1 & 4 & 3 \\
\hline D & $2.0-2.9$ & 15 & 3.25 & 0 & 1 & 1 & 0 & 0 & 1 & 1 & 0 & 5 & 1 & 3 & 2 & 0 \\
\hline E & $3.0-3.9$ & 8 & 1.73 & 1 & 0 & 0 & 0 & 0 & 0 & 0 & 1 & 4 & 0 & 1 & 1 & 0 \\
\hline $\mathrm{F}$ & $4.0-4.9$ & 28 & 6.07 & 0 & 0 & 0 & 0 & 1 & 2 & 0 & 9 & 8 & 6 & 0 & 1 & 1 \\
\hline$G$ & $5.0-5.9$ & 78 & 6.91 & 4 & 3 & 0 & 4 & 1 & 5 & 5 & 14 & 16 & 16 & 3 & 6 & 1 \\
\hline $\mathrm{H}^{*}$ & $6.0-6.9$ & 139 & 30.15 & 2 & 14 & 4 & 10 & 4 & 9 & 6 & 9 & 18 & 33 & 10 & 13 & 7 \\
\hline | & $7.0-7.9$ & 58 & 12.58 & 2 & 5 & 9 & 4 & 1 & 0 & 5 & 1 & 10 & 4 & 4 & 7 & 6 \\
\hline$J$ & $\geq 8.0$ & 77 & 16.70 & 7 & 0 & 3 & 1 & 1 & 1 & 4 & 3 & 4 & 5 & 26 & 14 & 8 \\
\hline \multirow{2}{*}{\multicolumn{2}{|c|}{ Total }} & 461 & 100 & 21 & 24 & 21 & 24 & 9 & 29 & 26 & 37 & 66 & 73 & 49 & 50 & 32 \\
\hline & & & & & & 99 & & & \\
\hline
\end{tabular}

$\mathrm{H}^{\star}$ including the original strain which produced $6.0 \mathrm{U} / \mathrm{ml}$ 